\title{
Nutritional Recovery with a Soybean Diet after Weaning Reduces Lipogenesis but Induces Inflammation in the Liver in Adult Rats Exposed to Protein Restriction during Intrauterine Life and Lactation
}

\author{
Sílvia Regina de Lima Reis, ${ }^{1}$ Naoel Hassan Feres, ${ }^{1}$ \\ Leticia Martins Ignacio-Souza, ${ }^{1}$ Roberto Vilela Veloso, ${ }^{1}$ Vanessa Cristina Arantes, ${ }^{1}$ \\ Nair Honda Kawashita, ${ }^{2}$ Edson Moleta Colodel, ${ }^{3}$ Bárbara Laet Botosso, ${ }^{1}$ \\ Marise Auxiliadora de Barros Reis, ${ }^{1}$ and Márcia Queiroz Latorraca ${ }^{1}$ \\ ${ }^{1}$ Departamento de Alimentos e Nutrição, Faculdade de Nutrição, Universidade Federal de Mato Grosso (UFMT), \\ 78060-900 Cuiabá, MT, Brazil \\ ${ }^{2}$ Departamento de Química, Instituto de Ciências Exatas e da Terra, Universidade Federal de Mato Grosso (UFMT), \\ 78060-900 Cuiabá, MT, Brazil \\ ${ }^{3}$ Departamento de Clínica Médica Veterinária, Faculdade de Agronomia e Medicina Veterinária, \\ Universidade Federal de Mato Grosso (UFMT), 78060-900 Cuiabá, MT, Brazil \\ Correspondence should be addressed to Márcia Queiroz Latorraca; mqlator@gmail.com
}

Received 9 July 2014; Revised 23 October 2014; Accepted 18 November 2014

Academic Editor: Cristina E. Carnovale

Copyright (C) 2015 Sílvia Regina de Lima Reis et al. This is an open access article distributed under the Creative Commons Attribution License, which permits unrestricted use, distribution, and reproduction in any medium, provided the original work is properly cited.

\begin{abstract}
We evaluated the effects of postweaning nutritional recovery with a soybean flour diet on de novo hepatic lipogenesis and inflammation in adult rats exposed to protein restriction during intrauterine life and lactation. Rats from mothers fed with protein (casein) in a percentage of $17 \%$ (control, C) or 6\% (low, L) during pregnancy and lactation were fed with diet that contained $17 \%$ casein (CC and LC groups, resp.) or soybean (CS and LS groups, resp.) after weaning until 90 days of age. LS and CS rats had low body weight, normal basal serum triglyceride levels, increased ALT concentrations, and high HOMA-IR indices compared with LC and CC rats. The soybean diet reduced PPAR $\gamma$ as well as malic enzyme and citrate lyase contents and activities. The lipogenesis rate and liver fat content were lower in LS and CS rats relative to LC and CC rats. TNF $\alpha$ mRNA and protein levels were higher in LS and $\mathrm{CS}$ rats than in LC and CC rats. NF- $\kappa \mathrm{B}$ mRNA levels were lower in the LC and LS groups compared with the CC and LC groups. Thus, the soybean diet prevented hepatic steatosis at least in part through reduced lipogenesis but resulted in TNF $\alpha$-mediated inflammation.
\end{abstract}

\section{Introduction}

The liver has an important role in lipid metabolism, which includes the mobilization and synthesis of free fatty acids as well as the storage and export of lipids and lipoproteins [1]. Various drugs, nutritional factors, and genetic defects in energy metabolism can result in excess hepatic triacylglycerol accumulation (hepatic steatosis) [2]. Hepatic steatosis can be a benign condition, or it may evolve with inflammation (steatohepatitis), fibrosis, and cirrhosis, an altered spectrum termed nonalcoholic fatty liver disease (NAFLD) [3]. The most common disorder associated with NAFLD is insulin resistance [4].

Insulin resistance is a condition wherein higher than normal insulin levels are needed to provoke normal metabolic responses or where normal metabolic responses are not achieved with normal insulin concentrations. Depending on the primary site of involvement, the insulin resistance can be central (liver) or peripheral (muscle or fat tissue) [5]. In NAFLD, the initial site appears to be in the periphery, 
followed by or resulting in hepatic steatosis, which exacerbates hepatic insulin resistance and thus the degree of overall insulin resistance [6].

Peripheral insulin resistance increases the serum levels of free fatty acids derived from the lipolysis of triacylglycerol from white adipose tissue [7]; these fatty acids are taken up by the liver and used in the production of triacylglycerol [8]. In addition, chronic hyperinsulinemia resulting from overall insulin resistance promotes de novo hepatic lipogenesis through the upregulation of lipogenic transcription factors [2]. A transcription factor that participates in the development of fatty liver in rodents is SREBP-1c (sterol regulatory element-binding protein-1c) [9]. In the nucleus, SREBP-1c transcriptionally activates genes required for lipogenesis; this effect is mediated by insulin [10]. Peroxisome proliferatoractivated receptor gamma $(\operatorname{PPAR} \gamma)$ is another transcription factor involved in the development of hepatic steatosis in rodents [2]. In the liver, $\operatorname{PPAR} \gamma$ is usually expressed at very low levels [11], but its expression is markedly increased in animal models exhibiting insulin resistance and fatty livers [12].

Increases in oxidative stress and in factors that promote proinflammatory cytokine expression, such as interleukin (IL)-6 [13] and tumor necrosis factor- $\alpha(\mathrm{TNF} \alpha)$ [14], are implicated in the development of nonalcoholic steatohepatitis $(\mathrm{NASH})$, with the nuclear factor kappa B (NF- $\kappa \mathrm{B})$ playing a critical role in the modulation of proinflammatory transcription [15]. Moreover, several studies have documented the association of insulin resistance (liver and adipose tissue) with inflammation [16].

Protein restriction is associated with hepatic steatosis [17]. In our laboratory, we have studied an experimental model of protein restriction in early life that demonstrates deficits in insulin secretion [18] and liver insulin resistance [19] in adulthood. We use soybean flour diets as an alternative lowcost and high-quality protein source to feed these animals in an attempt to prevent and/or to treat the long-term consequences of malnutrition [20]. This choice was motivated by scientific evidence showing that the consumption of soy protein and isoflavones may exert beneficial effects on glucoregulation, lipotoxicity in the liver, and lipidemia by acting on a wide spectrum of biochemical and molecular activities $[21,22]$.

Interestingly, we observed that serum insulin concentrations were increased in animals reared on a soybean diet, but alterations occurred in the early steps of the hepatic insulin signal transduction pathway, indicating hepatic insulin resistance $[23,24]$. Moreover, the weight and lipid content of the white adipose tissue as well as the lipolysis rate by isoproterenol in white adipocytes were decreased in rats fed the soybean diet [25]. Thus, the aim of this study was to investigate the effects of nutritional recovery after weaning with a soybean flour diet on de novo hepatic lipogenesis and inflammation in adult rats exposed to protein restriction during intrauterine life and lactation.

\section{Materials and Methods}

2.1. Animals and Diets. The experimental procedures involving rats were performed in accordance with the guidelines of the Brazilian College for Animal Experimentation (COBEA) and were approved by the ethics committee at the Federal University of Mato Grosso. Male and virgin female Wistar rats (85-90 days old) were obtained from the university's own breeding colony. Mating was performed by housing males with females overnight ( 1 male and 4 females), and pregnancy was confirmed by the presence of sperm in vaginal smears. Pregnant females were separated at random and maintained from the first day of pregnancy until the end of lactation on isocaloric diets containing $6 \%$ (low protein (LP) diet, $n=$ 6) or $17 \%$ (control (C) diet, $n=8$ ) protein. Spontaneous delivery occurred at day 22 of pregnancy, after which, at 3 days of age, large litters were reduced to eight pups to ensure a standard litter size per mother. After weaning in the 4 th week, the males were divided into five groups: CC, consisting of offspring born to and suckled by mothers fed a $\mathrm{C}$ diet and subsequently fed the same diet after weaning until 90 days of age; CS, consisting of offspring born to and suckled by mothers fed a $\mathrm{C}$ diet and subsequently fed a soybean flour diet with $17 \%$ protein after weaning until 90 days of age; LL, consisting of offspring born to mothers fed an LP diet and subsequently fed the same diet after weaning until 90 days of age; LC, consisting of offspring born to mothers fed an LP diet and subsequently fed a $\mathrm{C}$ diet after weaning until 90 days of age; and LS, consisting of offspring born to mothers fed an LP diet and subsequently fed a soybean flour diet containing $17 \%$ protein after weaning until 90 days of age. The diets have been previously described $[23,26]$. Throughout the experimental period, the rats were given free access to food and water. The rats were weighed at birth and at 30 and 90 days. All experimental procedures were performed at 90 days of age.

2.2. Sample Collection and Analyses. The homeostasis model assessment of insulin resistance (HOMA-IR) index was assessed from the basal glucose and insulin concentrations using the following formula: basal glucose $(\mathrm{mmol} / \mathrm{L}) \times$ basal insulin $(\mu \mathrm{U} / \mathrm{mL}) / 22.5$.

Fed rats were euthanized, and liver tissue samples were quickly removed, frozen immediately in liquid nitrogen, and stored at $-80^{\circ} \mathrm{C}$ to determine malic enzyme (ME) and citrate lyase (CLY) activities; hepatic fat content; and nSREBP1c (nuclear sterol regulatory element-binding protein-1c), PPAR $\gamma, \mathrm{ME}, \mathrm{CLY}, \mathrm{TNF} \alpha, \mathrm{NF}-\kappa \mathrm{B}$, and IL-10 expression levels by immunoblotting. The mRNA expression levels of TNF $\alpha$, IL-6, IL-10, and NF- $\kappa$ B were determined by real-time PCR. The remainder of the liver was removed and preserved for histologic analysis. Liver samples were obtained for in vivo lipogenesis measurements from another group of rats in the fed state. Biochemical and hormonal measurements were obtained in the fasting state. Blood glucose concentrations were determined using a portable glucose meter (Accu-Chek, Roche Diagnostics, Mannheim, Germany). After euthanasia, aliquots of serum obtained by centrifugation were used to measure total serum protein [27], serum triacylglycerol, and hepatic aminotransferase concentrations (BT-3000 Plus, Wiener Lab, Rosario, Argentina). Serum insulin concentrations were determined by radioimmunoassay [28]. 
2.3. Measurement of Enzymatic Activity in the Liver. ME activity was assayed by the method of Ochoa [29] in accordance with the modifications proposed by Hsu and Lardy [30]. CLY activity was assayed as described by Srere [31].

2.4. Liver In Vivo Fatty Acid Synthesis. ${ }^{3} \mathrm{H}_{2} \mathrm{O}(3 \mathrm{mCi})$ dissolved in $0.3 \mathrm{~mL}$ saline was administered to anesthetized rats by intraperitoneal injection $1 \mathrm{~h}$ before the experiment. The liver tissue was immediately removed and weighed. Total lipid from the liver was evaluated according to Folch et al. [32]. ${ }^{3} \mathrm{H}_{2} \mathrm{O}$ was removed from the inferior phase (predominantly chloroform) by washing three times with a superiorphase mixture. After each shaking, the tubes were briefly centrifuged to sharpen the phase boundary, and the superior phase was aspirated and discarded. Isolation and counting of ${ }^{3} \mathrm{H}_{2} \mathrm{O}$-labeled fatty acids from the inferior phase was performed as previously described [33]. For the calculations of lipid synthesis in experiments with ${ }^{3} \mathrm{H}_{2} \mathrm{O}$, it was assumed that the specific activity of intracellular water was identical to that of plasma water, which was determined directly in aliquots of diluted (20 times) plasma. The rates of tissue lipid synthesis were calculated assuming that each fatty acid incorporated into triacylglycerol contained 13.3 atoms of tritium.

2.5. Liver Histology. Paraffin-embedded sections were stained with hematoxylin and eosin. Histologic evaluation included a semiquantitative analysis of the presence of micro- and macrovesicular fat. All sections were coded and analyzed blindly by the pathologist without knowledge of related characteristics or diet. The degree of fat accumulation was graded on a scale of 0 to 4 as follows: $0=$ no evidence of or barely visible microvesicular fat; $1+=<25 \% ; 2+=25 \%$ to $49 \%$; $3+=50 \%$ to $75 \% ; 4+=$ fat involving $>75 \%$ of the lobule.

2.6. Immunoblot Analysis of ME and CLY in Total Liver Extracts. One frozen liver fragment was homogenized in freshly prepared buffer (1\% Triton X-100, $100 \mathrm{mmol} / \mathrm{L}$ Tris- $\mathrm{HCl}$ (pH 7.4), $100 \mathrm{mmol} / \mathrm{L}$ sodium pyrophosphate, $100 \mathrm{mmol} / \mathrm{L}$ sodium fluoride, $10 \mathrm{mmol} / \mathrm{L}$ EDTA, $10 \mathrm{mmol} / \mathrm{L}$ sodium orthovanadate, $2.0 \mathrm{mmol} / \mathrm{L}$ PMSF, and $0.1 \mathrm{mg}$ aprotinin $/ \mathrm{mL}$ ). Insoluble material was removed by centrifugation for $20 \mathrm{~min}$ at $12000 \mathrm{~g}$ at $4^{\circ} \mathrm{C}$. Protein concentrations were determined by the Bradford method [34]. Samples containing $40 \mu \mathrm{g}$ of protein from each experimental group were incubated with $4 \mathrm{x}$ concentrated Laemmli sample buffer [35] and $15 \mathrm{mg}$ of DTT and assayed on polyacrylamide gels at $120 \mathrm{~V}$ for $90 \mathrm{~min}(10 \%$ gels for $\mathrm{ME}$ and CLY). The electrotransfer of proteins to nitrocellulose membranes (Bio-Rad) was per formed for $90 \mathrm{~min}$ at $120 \mathrm{~V}$ in buffer containing methanol and SDS. After ascertaining transfer efficiency by Ponceau staining, the membranes were blocked with $5 \%$ albumin in Tween-Tris buffered saline (TTBS) $(10 \mathrm{mmol} / \mathrm{L}$ Tris, $150 \mathrm{mmol} / \mathrm{L} \mathrm{NaCl}, 0.5 \%$ Tween 20) overnight at $4^{\circ} \mathrm{C}$. ME, CLY, TNF $\alpha, \mathrm{NF}-\kappa \mathrm{B}$, and IL-10 were detected in the membranes after a $2 \mathrm{~h}$ incubation at room temperature with anti-ME1 rabbit monoclonal IgG (Sigma-Aldrich, St. Louis, MO, USA), anti-CLY polyclonal IgG (Cell Signaling Technology Inc., USA), anti-TNF $\alpha$ rabbit polyclonal IgG, anti-NF- $\kappa$ B mouse monoclonal IgG, or antiIL-10 goat polyclonal IgG (Santa Cruz Biotechnology, USA) diluted 1:500 in TTBS containing 3\% dry albumin. GAPDH was included as a protein loading marker. Enhanced chemiluminescence was performed (SuperSignal West Pico, Pierce) after incubation with the appropriate horseradish peroxidaseconjugated secondary antibody.

2.7. Immunoblot Analysis of SREBP-1c and PPAR $\gamma$ in Nuclear Extracts. Hepatic nuclear extracts were obtained as described by Siegrist-Kaiser et al. [36]. The protein concentrations of the nuclear extracts were determined by the Bradford assay [34]. Nuclear extracts $(20 \mu \mathrm{g})$ were separated by SDS-PAGE in $10 \%$ gels according to Milanski et al. [37]. The membranes were blocked with $5 \%$ skim milk in Tween-Tris-buffered saline (TTBS) (10 mmol/L Tris, $150 \mathrm{mmol} / \mathrm{L} \mathrm{NaCl}, 0.5 \%$ Tween 20$)$ overnight at $4^{\circ} \mathrm{C}$. nSREBP-1c and PPAR $\gamma$ were detected in the membranes after a $2 \mathrm{~h}$ incubation at room temperature with anti-SREBP-1c rabbit polyclonal IgG and anti-PPAR $\gamma$ mouse polyclonal IgG (Santa Cruz Biotechnology; diluted 1:500 in TTBS containing 3\% dry skimmed milk). Histone was used as a marker of the subcellular fraction and a protein loading marker. Enhanced chemiluminescence was performed (Super Signal West Pico, Pierce) after incubation with the appropriate horseradish peroxidase-conjugated secondary antibody.

2.8. RNA Preparation and Real-Time RT-PCR. Total RNA was isolated from frozen liver samples by TRIzol reagent (Invitrogen, USA), according to the supplier's instructions. Three micrograms of total RNA were transcribed into cDNA with High Capacity reverse transcriptase (Applied Biosystems). Primers specific for rat TNF $\alpha$ (Rn00563005_ml), IL-6 (Rn99999011_m1), IL-10 (Rn00563409_m1), NF- $\kappa$ B (Rn01399583_ml), and glyceraldehyde-3-phosphate dehydrogenase (GAPDH) (Rn01775763_g1) were obtained from Applied Biosystems. GAPDH was used as the endogenous control. PCR was carried out in duplicate on a Step One system using TaqMan Gene Expression Master Mix (Applied Biosystems). The cDNA was amplified under the following conditions: $95^{\circ} \mathrm{C}$ for $10 \mathrm{~min}$ for denaturation and then 40 cycles of $95^{\circ} \mathrm{C}$ for $15 \mathrm{~s}, 60^{\circ} \mathrm{C}$ for $20 \mathrm{~s}$, and $72^{\circ} \mathrm{C}$ for $15 \mathrm{~s}$, followed by extension at $72^{\circ} \mathrm{C}$ for $10 \mathrm{~min}$. Real-time data were analyzed using the Step One System (Applied Biosystems).

2.9. Statistical Analysis. The results are expressed as the means with their respective standard deviations for the number of rats indicated in parentheses. Bartlett's test for the homogeneity of variances was initially used to determine whether the data complied with the assumptions necessary for a parametric ANOVA. When necessary, the data were $\log$ transformed to correct for variance in heterogeneity or nonnormality [38]. A two-way ANOVA (i.e., effects of nutritional status in early life and diet) was used to compare the data from the CC, CS, LC, and LS groups. A one-way ANOVA was used to assess whether the diets were effective at improving the nutritional status of the LC, LS, and LL groups. When necessary, these analyses were complemented by the least significant difference test to determine the significance of the individual differences. $P<0.05$ indicated statistical significance. All statistical comparisons were conducted using the Statistica software package (Stat-Soft). 
TABLE 1: Somatic, biochemical, and hormonal parameters from adult rats maintained on control (CC and LC groups) soybean flour (CS and LS groups), or low protein (LL group) diet after weaning until 90 days age.

\begin{tabular}{|c|c|c|c|c|c|}
\hline \multirow{2}{*}{ Variables } & \multicolumn{5}{|c|}{ Groups } \\
\hline & $\mathrm{CC}$ & CS & $\mathrm{LC}$ & LS & LL \\
\hline \multicolumn{6}{|l|}{ Body weight (g) } \\
\hline Initial & $\begin{array}{c}78 \pm 13 \\
(10)\end{array}$ & $\begin{array}{l}71 \pm 11 \\
(10)\end{array}$ & $\begin{array}{c}24 \pm 6^{*} \\
(12)\end{array}$ & $\begin{array}{c}23 \pm 3^{*} \\
(12)\end{array}$ & $\begin{array}{c}28 \pm 3 \\
(13)\end{array}$ \\
\hline Final & $\begin{array}{c}434 \pm 53 \\
(10)\end{array}$ & $\begin{array}{c}364 \pm 20^{\#} \\
(11)\end{array}$ & $\begin{array}{c}333 \pm 23^{* a} \\
(12)\end{array}$ & $\begin{array}{c}263 \pm 13^{\# * b} \\
(12)\end{array}$ & $\begin{array}{c}154 \pm 34^{\mathrm{c}} \\
\text { (13) }\end{array}$ \\
\hline Serum total protein $(\mathrm{g} / \mathrm{L})$ & $\begin{array}{c}56 \pm 2 \\
(6)\end{array}$ & $\begin{array}{c}55 \pm 3 \\
(7)\end{array}$ & $\begin{array}{c}58 \pm 3^{\mathrm{a}} \\
\quad(11)\end{array}$ & $\begin{array}{c}56 \pm 2^{\mathrm{a}} \\
(7)\end{array}$ & $\begin{array}{c}50 \pm 3^{b} \\
(6)\end{array}$ \\
\hline Serum triglycerides $(\mathrm{mmol} / \mathrm{L})$ & $\begin{array}{c}0.6 \pm 0.3^{\mathrm{B}} \\
(5)\end{array}$ & $\begin{array}{c}0.6 \pm 0.1^{\mathrm{B}} \\
(5)\end{array}$ & $\begin{array}{c}1.2 \pm 0.5^{\mathrm{Aa}} \\
(7)\end{array}$ & $\begin{array}{c}0.6 \pm 0.1^{\mathrm{Bb}} \\
(7)\end{array}$ & $\begin{array}{c}1.0 \pm 0.4^{\mathrm{ab}} \\
(6)\end{array}$ \\
\hline Serum glucose $(\mathrm{mmol} / \mathrm{L})$ & $\begin{array}{c}3.9 \pm 1.2 \\
(9)\end{array}$ & $\begin{array}{c}4.7 \pm 1.1 \\
(7)\end{array}$ & $\begin{array}{c}4.2 \pm 1.1 \\
(10)\end{array}$ & $\begin{array}{c}4.5 \pm 1.0 \\
(7)\end{array}$ & $\begin{array}{c}4.2 \pm 1.8 \\
(8)\end{array}$ \\
\hline Serum insulin $(\mu \mathrm{U} / \mathrm{mL})$ & $\begin{array}{c}12 \pm 4 \\
(9)\end{array}$ & $\begin{array}{c}33 \pm 8^{\#} \\
(7)\end{array}$ & $\begin{array}{c}11 \pm 3^{b} \\
(10)\end{array}$ & $\begin{array}{c}26 \pm 10^{\# \mathrm{a}} \\
(7)\end{array}$ & $\begin{array}{c}13 \pm 3^{b} \\
(8)\end{array}$ \\
\hline HOMA-IR & $\begin{array}{c}2.1 \pm 0.7 \\
\quad(9)\end{array}$ & $\begin{array}{c}6.6 \pm 1.5^{\#} \\
(7)\end{array}$ & $\begin{array}{c}2.2 \pm 0.9^{\mathrm{b}} \\
(10)\end{array}$ & $\begin{array}{c}5.3 \pm 2.6^{\# \mathrm{a}} \\
(7)\end{array}$ & $\begin{array}{c}2.5 \pm 1.4^{\mathrm{b}} \\
(8)\end{array}$ \\
\hline $\operatorname{ALT}(\mathrm{U} / \mathrm{L})$ & $\begin{array}{c}28 \pm 6 \\
(5)\end{array}$ & $\begin{array}{c}43 \pm 8^{\#} \\
(5)\end{array}$ & $\begin{array}{c}45 \pm 13^{*} \\
(7)\end{array}$ & $\begin{array}{c}51 \pm 12^{\# *} \\
(7)\end{array}$ & $\begin{array}{c}54 \pm 6 \\
(6)\end{array}$ \\
\hline AST (U/L) & $\begin{array}{c}104 \pm 25 \\
(5)\end{array}$ & $\begin{array}{c}163 \pm 55^{\#} \\
(5)\end{array}$ & $\begin{array}{c}177 \pm 64^{*} \\
(7)\end{array}$ & $\begin{array}{c}177 \pm 54^{\# *} \\
(7)\end{array}$ & $\begin{array}{c}208 \pm 39 \\
(6)\end{array}$ \\
\hline$\gamma \mathrm{GT}(\mathrm{U} / \mathrm{L})$ & $\begin{array}{c}9 \pm 2^{\mathrm{AB}} \\
(5)\end{array}$ & $\begin{array}{c}6 \pm 4^{\mathrm{B}} \\
(5)\end{array}$ & $\begin{array}{c}8 \pm 3^{\mathrm{ABab}} \\
(7)\end{array}$ & $\begin{array}{c}10 \pm 2^{\mathrm{Aa}} \\
(7)\end{array}$ & $\begin{array}{c}6 \pm 3^{b} \\
(6)\end{array}$ \\
\hline $\mathrm{ALP}(\mathrm{U} / \mathrm{L})$ & $\begin{array}{l}144 \pm 21 \\
(5)\end{array}$ & $\begin{array}{c}141 \pm 16 \\
(5)\end{array}$ & $\begin{array}{c}178 \pm 33^{* \mathrm{~b}} \\
(7)\end{array}$ & $\begin{array}{c}199 \pm 27^{* \mathrm{~b}} \\
(7)\end{array}$ & $\begin{array}{c}492 \pm 66^{\mathrm{a}} \\
(6)\end{array}$ \\
\hline
\end{tabular}

\section{Results}

At the beginning of the recovery phase, LC, LS, and LL rats had similar body weights, and in all cases, these were significantly lower than those of the CC and CS rats. Body weight at the end of the experimental period was significantly lower in the LC and LS groups than in the CC and CS groups $(P<0.001)$. Rats maintained on a soybean flour diet after weaning (LS and CS groups) had a lower final body weight than those fed a casein diet (LC and CC groups) $(P<0.001)$. Although LS rats reached a higher final body weight than LL rats $(P<0.001)$, their weights were still significantly lower than those of LC rats $(P<0.001)$. Total serum protein concentrations did not differ among the CC, CS, LC, and LS groups. The LS and LC rats had higher total serum protein levels than rats from the LL group $(P<0.05)$. Serum triacylglycerol levels were higher in the LC group than in the LS, CS, and CC groups. In the LS group, serum triacylglycerol concentrations were lower relative to those of LC rats but did not differ from those exhibited by the LL rats. Serum insulin concentrations were higher in rats fed a soybean diet (CS and LS groups) than in rats fed a casein diet (CC and LC groups) $(P<0.0001)$. Basal serum glucose levels were not significantly different among the groups. The HOMA-IR index was higher in rats fed a soybean diet than in those reared on casein $(P<0.0001)$. Similar glycemia levels, but higher insulinemia and HOMA-IR indices, were recorded in LS rats relative to the LL and LC groups. There was no difference in HOMA-IR index or serum insulin concentrations between the LL and LC groups. Serum levels of alanine aminotransferase (ALT) were higher in the LS and LC groups than in the CS and CC groups $(P<0.01)$ and in rats maintained on a soybean diet (LS and CS rats) relative to those fed a casein diet (LC and CC rats) $(P<$ 0.05). There was no difference in ALT levels between the LL, LS, and LC groups. Serum aspartate aminotransferase (AST) levels did not differ among the groups. Levels of serum gamma-glutamyl-transpeptidase $(\gamma \mathrm{GT})$ in the LS group were significantly higher than those of the CS group but similar to those of the CC and LC groups. The LS rats had significantly higher $\gamma \mathrm{GT}$ levels than the LL rats, but they were similar to those of the LC group. Alkaline phosphatase (ALP) levels were significantly higher in the LS and LC groups than in the CS and CC groups $(P<0.01)$. The LS and LC groups showed ALP concentrations that were similar to each other and significantly lower than those observed in the LL group (Table 1).

Hepatocellular lipid accumulation (steatosis) was assessed in liver sections using the conventional hematoxylin-eosin staining technique (Figure 1(a)). Liver histology revealed that rats fed a soybean diet did not show an abnormal accumulation of fat in their livers because $100 \%$ of liver specimens 

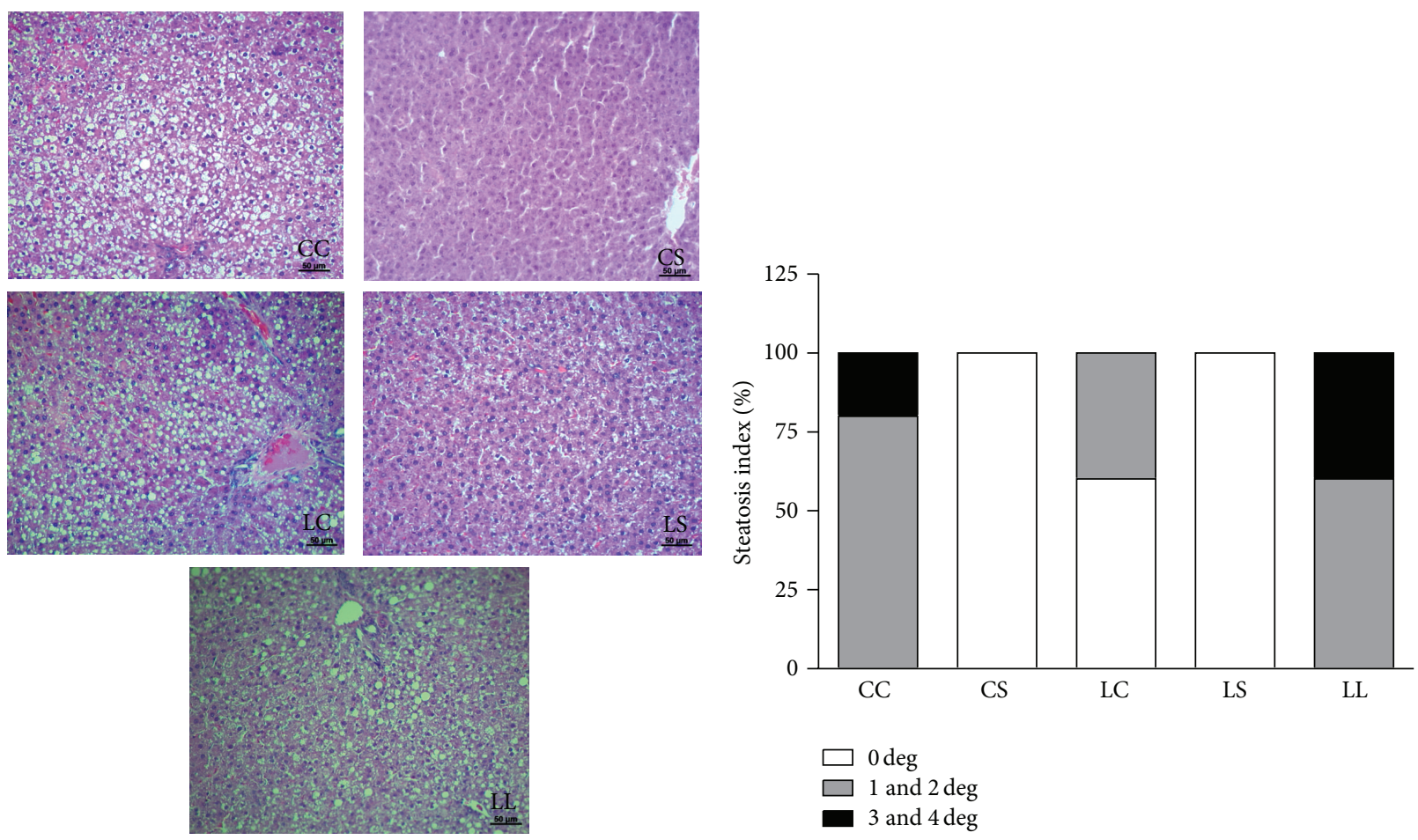

(a)
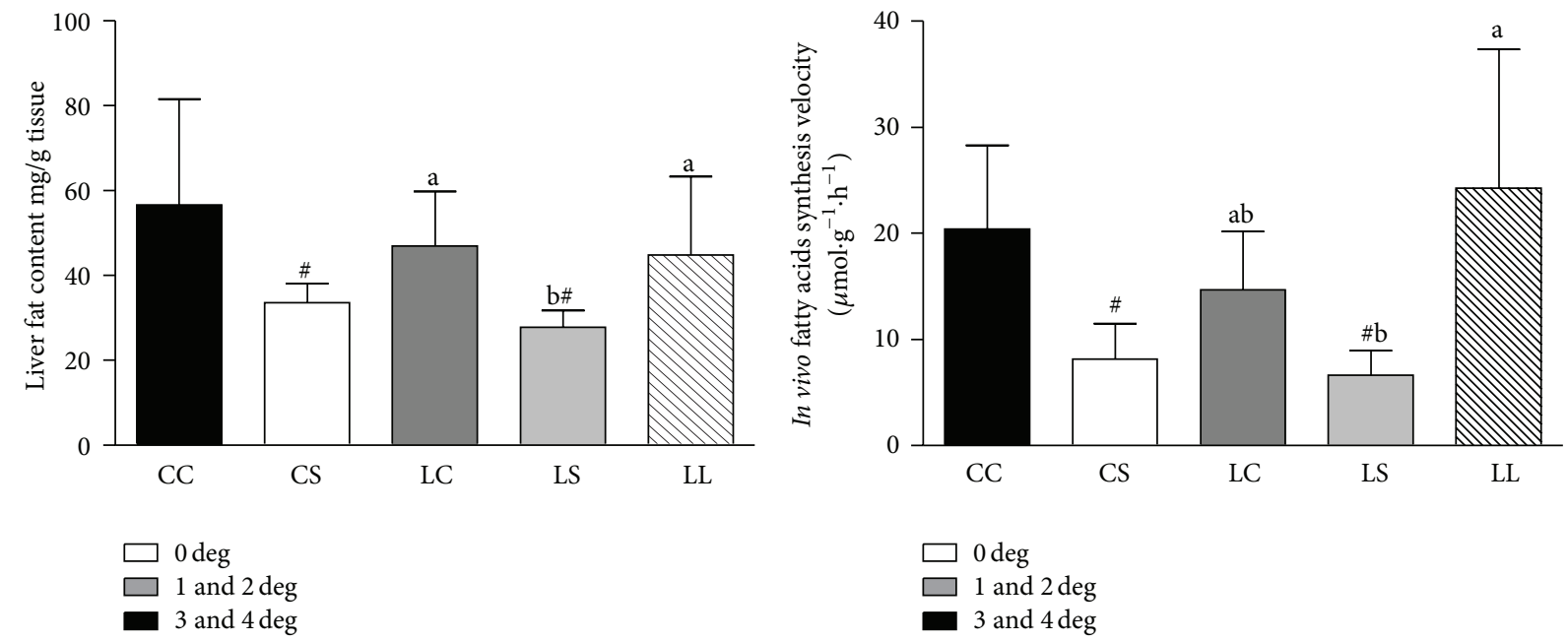

(c)

(d)

FIGURE 1: Representative photomicrographs of hematoxylin-eosin stained liver sections (a), steatosis index (b), liver fat content (c), and hepatic in vivo fatty acids synthesis rate (d) in adult rats maintained on control (CC and LC), soybean flour (CS and LS) or low-protein (LL) diets after weaning until 90 days of age. The values are expressed as the mean \pm SD ( $n=4-7$ rats). ${ }^{*}$ Mean values were significantly different from the casein diet (two-way ANOVA). Means with different superscript minuscule letters are significantly different by one-way ANOVA followed by a least significant difference (LSD) test $(P<0.05)$.

from the LS and CS groups were graded as 0. In the LC group, $60 \%$ of liver specimens were graded as 0 and $40 \%$ as 1 or 2 , whereas in the CC group, $80 \%$ were graded 1 or 2 and $20 \%$ as 3 or 4 . In the LL group, $60 \%$ were graded 1 or 2 and $40 \%$ as 3 or 4 (Figure 1(b)). The hepatic fat content (Figure 1(c)) was reduced in rats fed a soybean diet (LS and CS groups) compared with rats fed a casein diet (LC and CC groups) $(P<0.001)$. The LS group had lower hepatic fat content than the LC and LL groups. Moreover, rats fed the soybean flour diet (CS and LS groups) exhibited lower fatty acid synthesis rates compared with those fed the casein diet (CC and LC rats) $(P<0.001)$. The fatty acid synthesis rate in the LS group was lower than that of the LL group and similar to that observed in the LC group (Figure 1(d)).

nSREBP-1c protein levels were similar across the CS, CC, LS, and LC groups. However, the LS and LC groups showed significantly higher nSREBP-1c than the LL group (Figure 2(a)). Rats fed the soybean diet (CS and LS groups) had 

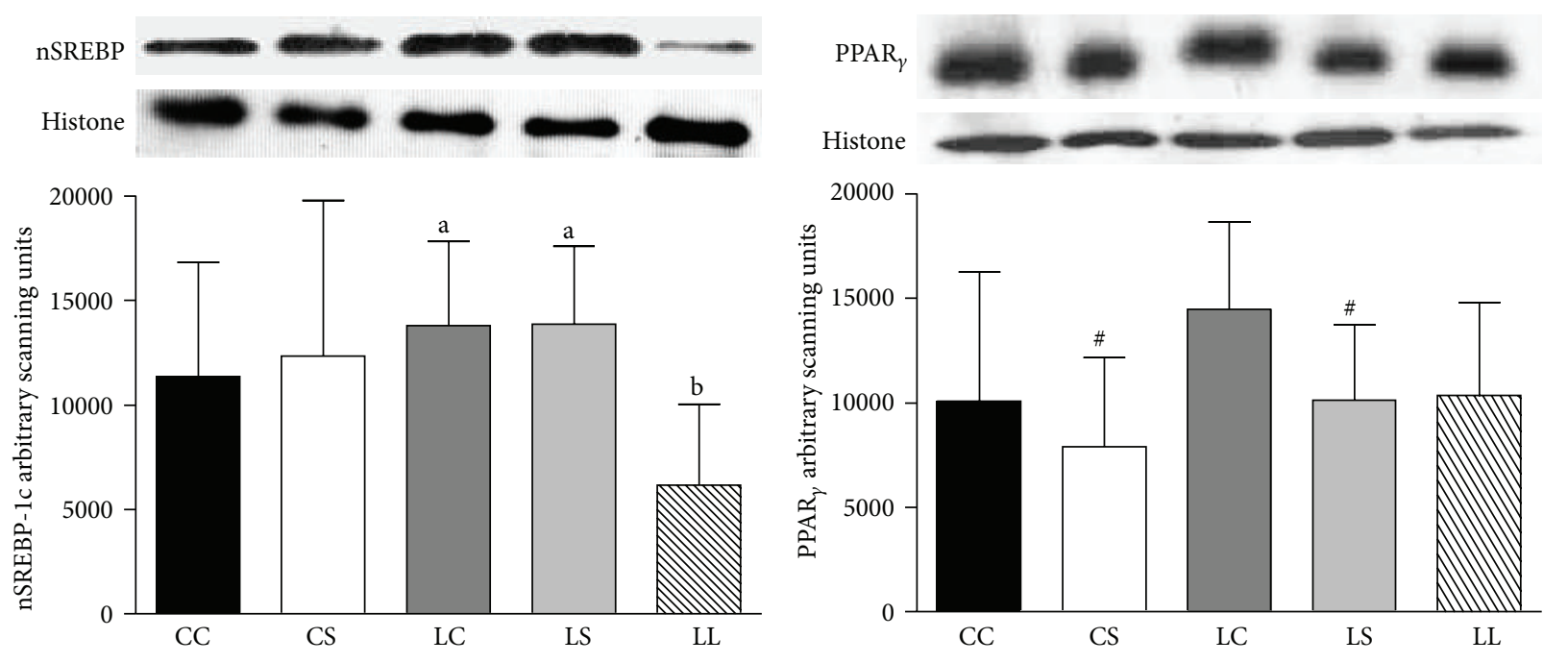

(a)

(b)

FIGURE 2: Immunoblot analysis of SREBP-1c (a) and PPAR $\gamma$ (b) in nuclear extracts from livers of rats fed with casein (CC and LC), soybeanflour (CS and LS), or low-protein (LL) diets after weaning. The values are expressed as the mean \pm SD $\left(n=4-7\right.$ rats). ${ }^{*}$ Mean values were significantly different from the casein diet (two-way ANOVA). Means with different superscript minuscule letters are significantly different by one-way ANOVA followed by a least significant difference (LSD) test $(P<0.05)$.

lower nPPAR $\gamma$ levels than those fed the casein diet (CC and LC groups $)(P<0.05)$. There was no difference in nPPAR $\gamma$ levels among the LL, LS, and LC groups (Figure 2(b)).

Liver ME and CLY contents were significantly lower in rats fed the soybean diet (CS and LS groups) relative to those fed the casein diet (CC and CS groups) $(P<0.05$ and $P<$ 0.01 , resp.). Livers from the LS group also exhibited lower ME and CLY contents than livers from the LL and LC groups (Figures 3(a) and 3(b)). The CS and LS groups showed lower $\mathrm{ME}$ and CLY activities compared with the CC and LC groups $(P<0.05$ and $P<0.01$, resp.). Moreover, ME and CLY activities were lower in the LS rats than in the LC rats, and these activities were significantly lower in both groups relative to the LL rats (Figures 3(c) and 3(d)).

mRNA levels of NF- $\kappa B$ (Figure 4(a)) and IL-6 (Figure 4(b)) were significantly reduced in the LC and LS groups relative to the CC and CS groups $(P<0.0001 ; P<0.005)$. No difference was observed in the NF- $\kappa$ B and IL- 6 mRNA expression among the LC, LS, and LL groups. TNF $\alpha$ mRNA levels (Figure 4(c)) were significantly higher in rats fed the soybean diet (LS and CS groups) than in those fed casein (LC and CC groups) $(P<0.01)$. The TNF $\alpha$ mRNA levels of the LS group were similar to those of the LC group and higher relative to the LL group $(P<0.05)$. IL-10 mRNA expression (Figure $4(\mathrm{~d})$ ) was not significantly different among the CC, CS, LC, and LS groups. However, the LS group exhibited significantly higher IL-10 mRNA expression than that observed in the LL and LC groups $(P<0.01)$.

NF- $\kappa$ B (Figure 5(a)) and IL-10 (Figure 5(b)) protein levels did not differ among the CC, CS, LC, and LS groups. However, LS and LC rats exhibited higher NF- $\kappa$ B protein levels than LL rats. No difference in IL-10 protein expression was observed among these groups. TNF $\alpha$ protein levels were higher in the $\mathrm{CS}$ and LS groups than in the CC and LC groups $(P<0.05)$, but no difference in TNF $\alpha$ levels was observed among the LL, LS, and LC groups (Figure 5(c)).

\section{Discussion}

In this study, rats recovered with the soybean diet showed low body weight and normalization of serum triacylglycerol concentrations, corroborating the well-known favorable effect of soy protein containing various levels of isoflavones on somatic parameters $[39,40]$ and serum triacylglycerol levels [41, 42]. However, contrary to the observations that soy protein reduces serum insulin levels $[42,43]$, we verify here, as in previous studies $[23,24,26]$, that the consumption of a soybean flour diet increased serum insulin concentrations. This effect may be attributable to genistein, which increases insulin secretion due to its ability to activate the cAMP-PKA pathway [26].

Interestingly, our animals fed with soybean protein showed low liver fat content (assessed by gravimetric and histologic assays) and liver insulin resistance as determined by the HOMA-IR index and confirmed by high serum ALT concentrations (a hepatic enzyme whose appearance reflects hepatic insulin resistance and NAFLD) [44]. It is also noteworthy that abundant lipid droplets (observed histologically) as well as elevated liver fat contents were observed in the rats from the CC group. Hepatic steatosis has also been reported by others [45], who attributed this effect to the elevated amounts of carbohydrates and calories provided by the AIN-93 diet. However, the CC rats exhibited HOMA-IR index values and serum ALT concentrations not compatible with metabolic alterations or hepatocellular injury. Moreover, although liver fat contents appeared to be comparable between the CC and LL groups, twice as many liver specimens from the LL group were graded as 3 or 4 . 

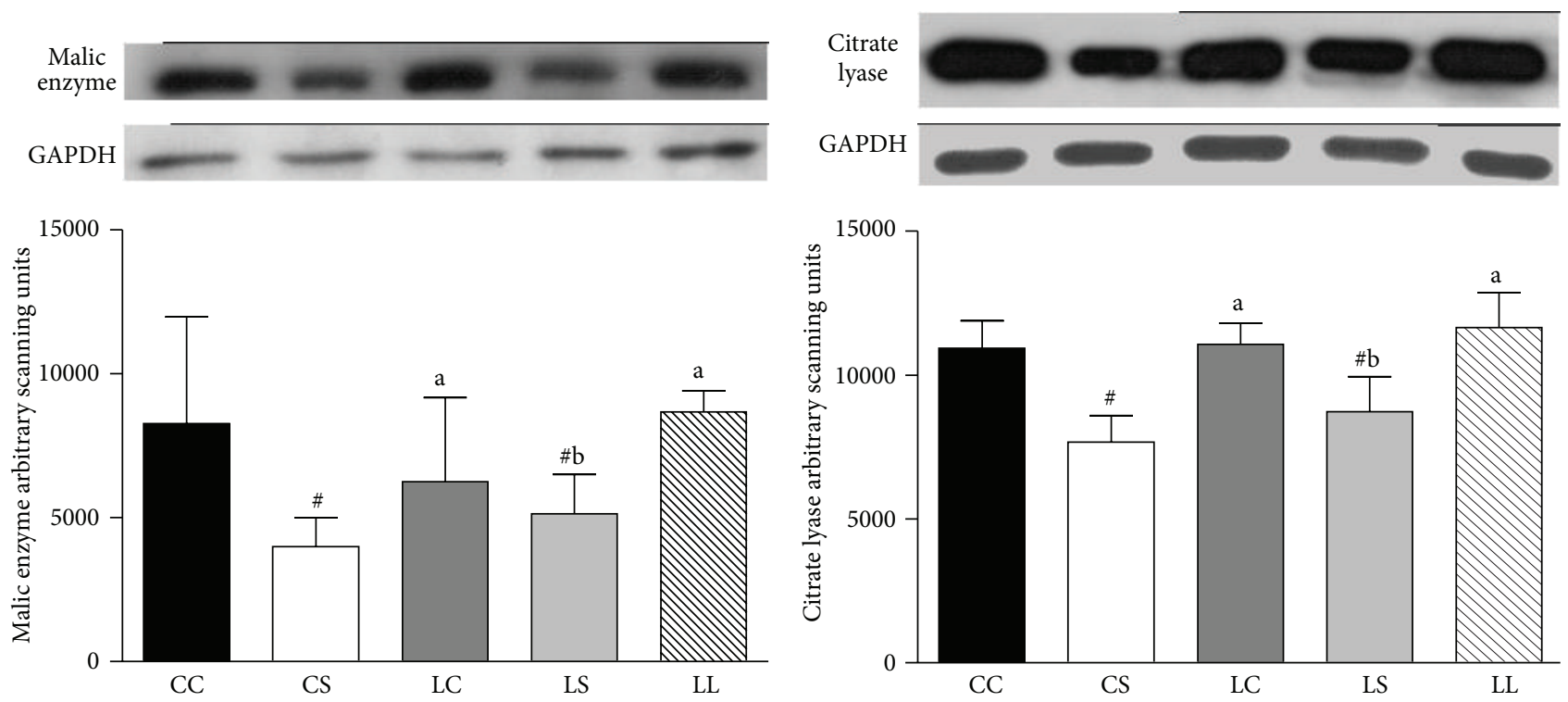

(a)

(b)

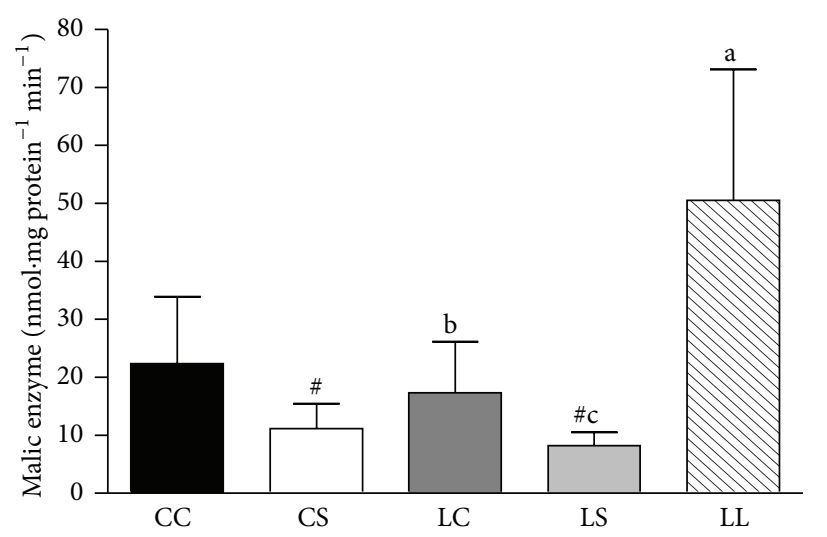

(c)

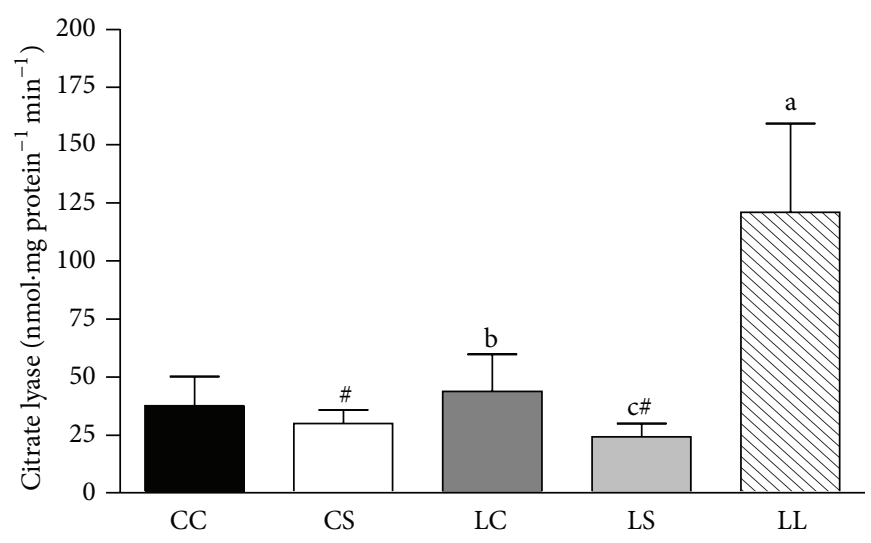

(d)

FIGURE 3: Immunoblot analysis of malic enzyme (a) and citrate lyase (b), activity of malic enzyme (c), and citrate lyase (d) in nuclear extracts from livers of rats fed with casein (CC and LC), soybean flour (CS and LS), or low-protein (LL) diets after weaning. The values are expressed as the mean \pm SD $\left(n=4-7\right.$ rats). ${ }^{\#}$ Mean values were significantly different from the casein diet (two-way ANOVA). Means with different superscript minuscule letters are significantly different by one-way ANOVA followed by a least significant difference (LSD) test $(P<0.05)$.

Liver insulin resistance results in the overexpression of SREBP-1c [46], whereas soy protein [42] and genistein [47] suppress the SREBP-1c levels. Thus, in this and in a previous study [37], the interplay between liver insulin resistance, which induces SREBP-1c overexpression, and other factors (e.g., genistein and soy protein) that suppress its expression resulted in no change in nSREBP-1c contents or SREBP-1c mRNA expression. An adequate explanation for the paradoxical association of liver insulin resistance with unmodified nSREBP-1c concentrations is the mild hyperinsulinemia and the euglycemia observed in our animals fed with soybean, as noted here and previously [24]. SREBP-1c expression has been shown to be stimulated by glucose and insulin and repressed by glucagon $[9,10,48]$. Interestingly, the repression of SREBP1c expression by soy protein has been attributed to decreased insulin: glucagon ratios [21]. In our animals, we previously observed reduced insulin: glucagon ratios in LC and LL rats compared with LS rats [24]. In that prior study [24], we observed that both the LC and LL groups exhibited lower serum insulin concentrations, lower liver insulin resistance, and basal glucose concentrations that were similar to those of LS rats. Surprisingly, only LL rats exhibited low nSREBP1c levels, but LL and LC rats had similar liver fat storage levels, and both had higher liver fat content than LS rats. In contrast, we observed that the soybean diet resulted in reduced expression of $\operatorname{PPAR} \gamma$, which targets the ME and CLY genes $[49,50]$. In agreement with this finding and with the observation that soy protein reduces the expression of ME [42], we verified low contents of both ME and CLY in liver samples from rats fed the soybean diet. Interestingly, studies have shown that the genetic deletion of PPAR $\gamma$ in the livers of lipodystrophic transgenic mice markedly attenuates the development of NAFLD, independent of the presence of hyperinsulinemia or hyperglycemia $[50,51]$. 


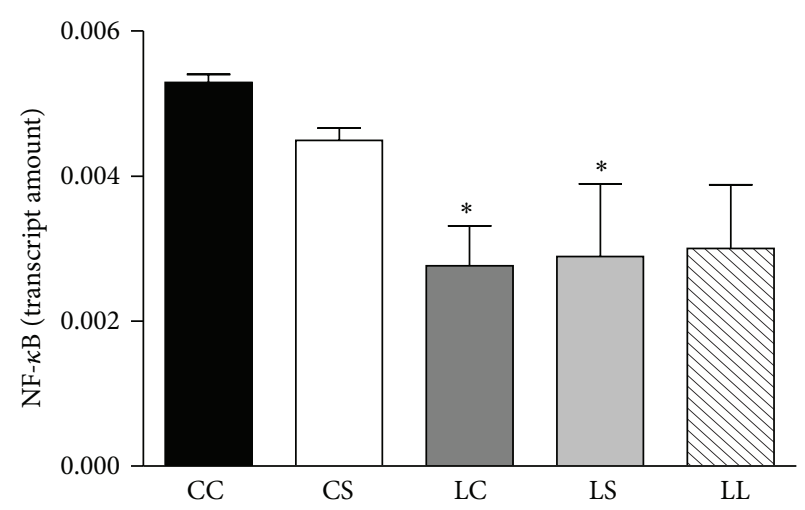

(a)

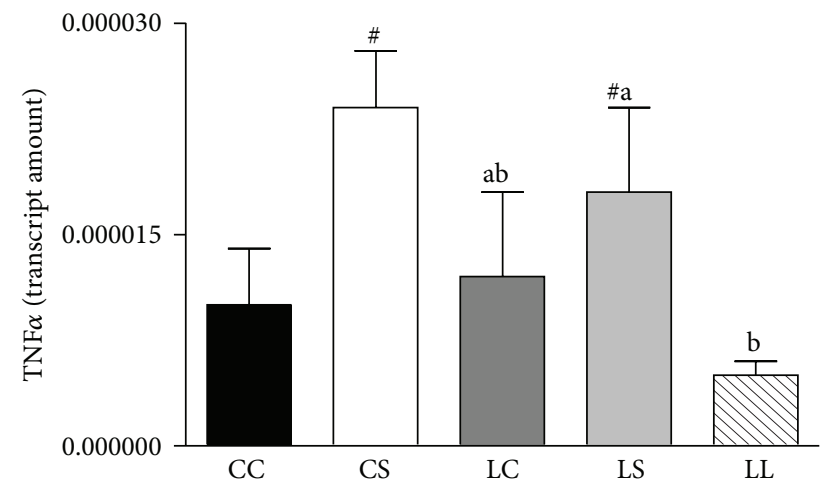

(c)

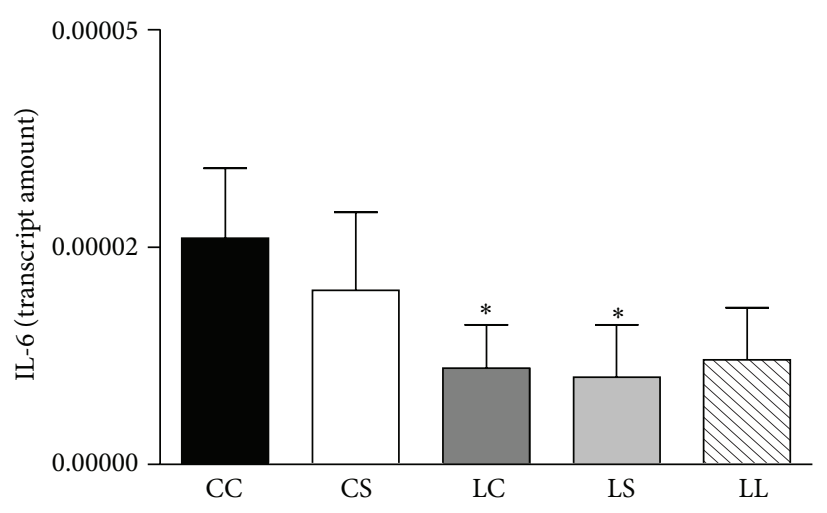

(b)

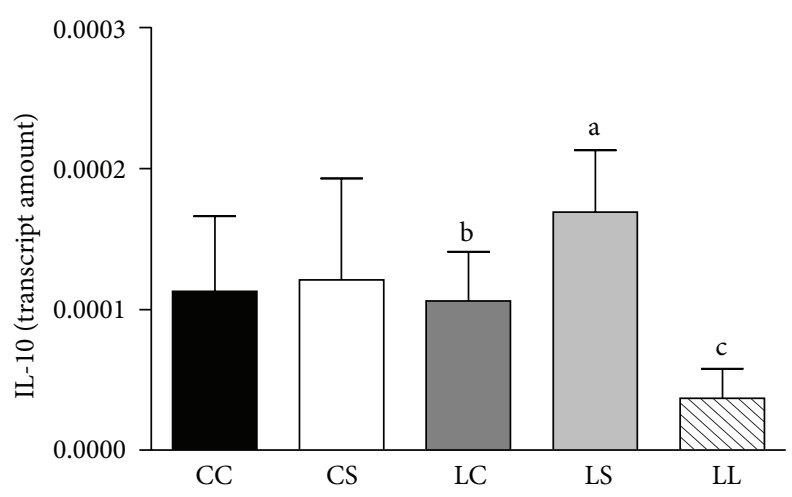

(d)

FIGURE 4: NF- $\kappa$ B (a), IL6 (b), TNF $\alpha$ (c), and IL10 (d) mRNA analyzed by real-time polymerase chain reaction in livers of adult rats maintained on casein control (CC and LC), soybean flour (CS and LS), or low-protein (LL) diets after weaning. The values are expressed as the mean \pm $\mathrm{SD}\left(n=4-7\right.$ rats). ${ }^{*}$ Mean values were significantly different from the casein diet (two-way ANOVA). ${ }^{*}$ Mean values were significantly different from rats born to mothers fed with $17 \%$ protein during pregnancy and lactation (two-way ANOVA). Means with different superscript minuscule letters are significantly different by one-way ANOVA followed by a least significant difference (LSD) test $(P<0.05)$.

Liver fat storage is also regulated by the integrated activities of cellular enzymes that catalyze lipid synthesis. Insulin acts as a key regulator of triglyceride biosynthesis in the liver by modulating enzymatic activities involved in the synthesis of fatty acids. In this study, both CLY and ME activities were reduced, and consequently, a decrease in de novo lipogenesis was observed in rats fed with soybean. It is well known that soy protein reduces ME activity in the liver [42]; however, in contrast to our observations, this suppressive effect was accompanied by low serum insulin concentrations and a reduced insulin: glucagon ratio [42]. In contrast to the animals fed soybean, in rats maintained on a low-protein diet, CLY and ME activity levels were elevated, resulting in an increase in the rate of de novo fatty acid synthesis, despite low levels of serum insulin. Two factors may have contributed to the increased activities of these enzymes: an increased sensitivity to insulin and the high carbohydrate levels of the low-protein diet. Some lines of evidence suggest that CLY and ME activity is stimulated by insulin and high carbohydrate intake $[52,53]$. Thus, the high CLY and ME activity levels appeared to determine the elevated rate of de novo fatty acid synthesis in the livers of rats from the LL group.

Curiously, the animals that were fed a soybean diet did not exhibit lipid accumulation in hepatocytes but did have high serum ALT concentrations, a marker of liver injury [54]. A potential induction factor for the hepatocellular injury and fibrosis observed in NAFLD is oxidative stress [1]. It has been shown that chronic genistein supplementation at more than $500 \mathrm{mg} / \mathrm{kg} /$ day adversely affects liver structure and function [55]. Moreover, genistein increases the level and activity of PPAR $\gamma[22,56]$, which, in the liver, plays a pivotal role in fatty acid catabolism by upregulating the expression of numerous genes involved in mitochondrial and peroxisomal fatty acid oxidation [57]. Consequently, activation of PPAR $\gamma$ can prevent and decrease hepatic fat storage [58], but the oxidation of fatty acids remains an important source of reactive oxygen species (ROS) in fatty livers [59]. This hypothesis is weakened by the fact that the amount of genistein contained in our diet was determined to be lower than $500 \mathrm{mg} / \mathrm{kg}$ body weight/day [23], yet our soybean-fed animals exhibited reduced PPAR $\gamma$ mRNA expression and unchanged PPAR $\gamma$ protein contents in the liver. However, these animals also exhibited reduced expression of liver acetyl-coenzyme A carboxylase beta $(\mathrm{ACC} \beta)$ [37], an enzyme localized in the mitochondrial membrane, where it is believed to regulate local malonylcoenzyme A levels, carnitine palmitoyltransferase I (CPT-1) activity, and fat oxidation. The lack of ACC $\beta$ is associated with continuous fatty acid oxidation and reduced fat storage 


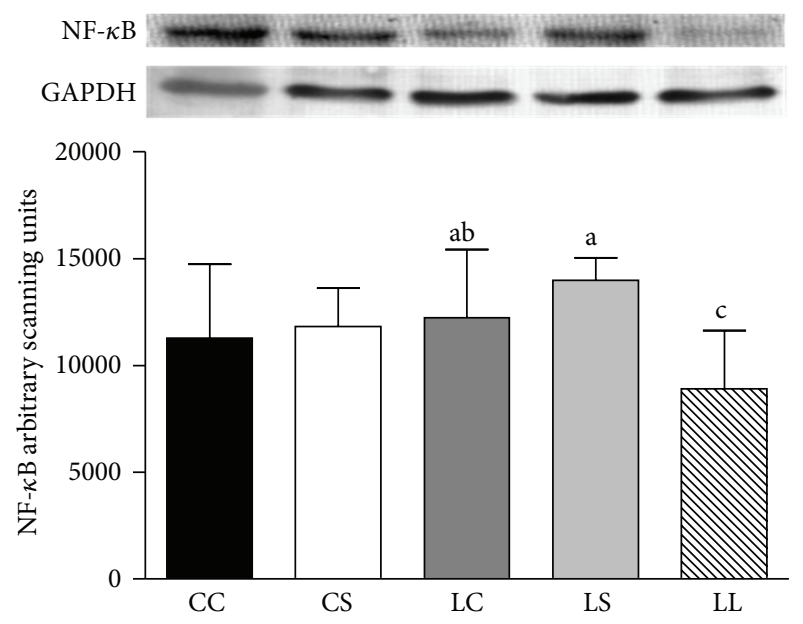

(a)

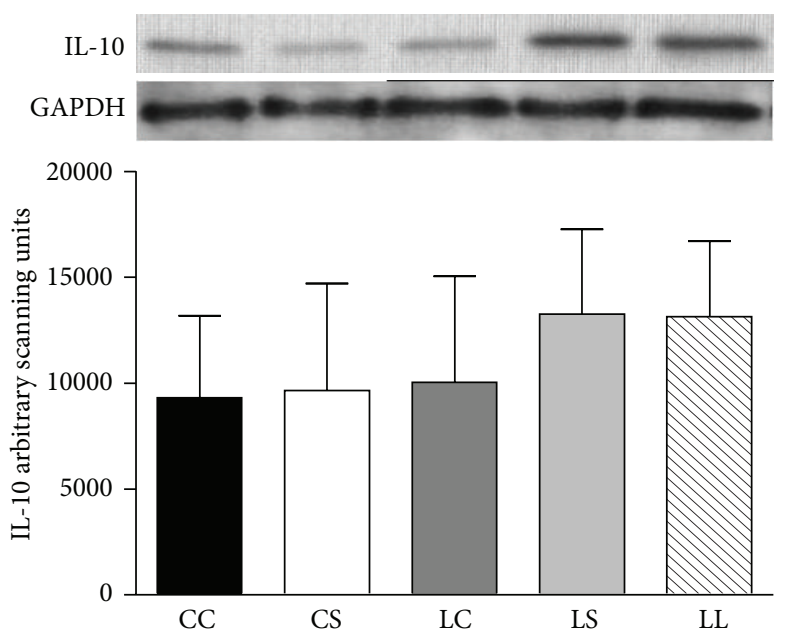

(b)

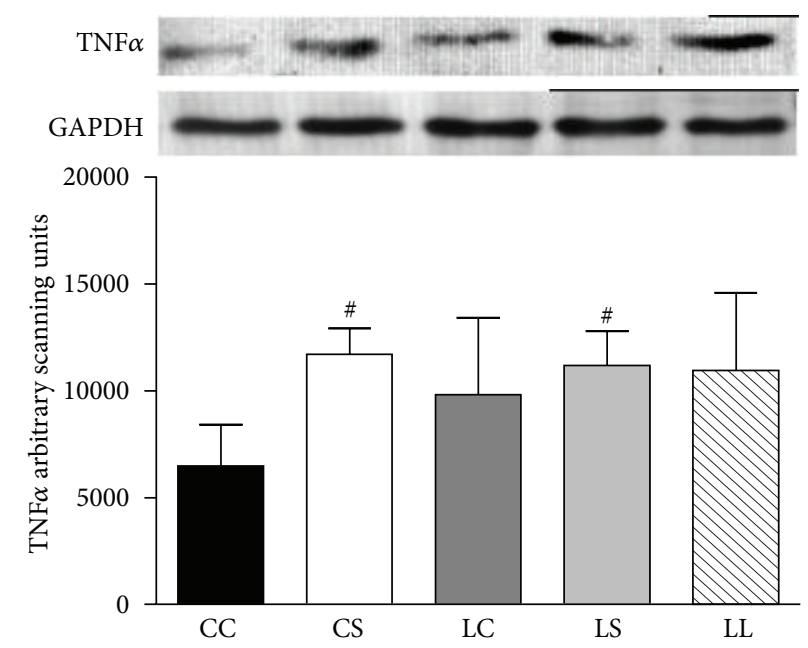

(c)

FIGURE 5: Immunoblot analysis of NF- $\kappa$ B (a), IL10 (b), and TNF $\alpha$ (c) in livers of adult rats maintained on casein control (CC and LC), soybean flour (CS and LS), or low-protein (LL) diets after weaning. The values are expressed as the mean \pm SD ( $n=4-7$ rats). ${ }^{\#}$ Mean values were significantly different from the casein diet (two-way ANOVA). Means with different superscript minuscule letters are significantly different by one-way ANOVA followed by a least significant difference (LSD) test $(P<0.05)$.

[60]. We also previously observed a reduction in nonprotein thiol levels in the livers of soybean-treated animals, indicating the consumption of nonprotein thiols by enhanced free radical generation (unpublished data).

A consequence of increased ROS includes the release of proinflammatory cytokines [2]. Hence, elevated ALT may reflect inflammation, which impairs insulin signaling in the liver. However, ALT is also a gluconeogenic enzyme, and increased ALT levels could therefore indicate impaired insulin signaling instead of liver injury. In our rats that were fed the soybean diet, the increased ALT, combined with high TNF $\alpha$ mRNA and protein levels, is consistent with inflammation. However, the unchanged NF- $\kappa \mathrm{B}$ expression in livers from these soybean-fed rats is indicative of the absence of fibrosis because NF- $\kappa$ B is considered a profibrotic marker [61]. The rats that were rescued from malnutrition in early life showed reduced transcription of NF- $\kappa$ B and IL-6 and increased transcription of IL-10 (an anti-inflammatory cytokine). However, neither NF- $\kappa$ B nor IL-10 protein levels were altered under these conditions. Given the elevated TNF $\alpha$ content, it is reasonable to suggest that the soybean diet increased NF- $\kappa \mathrm{B}$ activity. Interestingly, in the livers of rats maintained on the soybean diet, the expression of $\mathrm{TNF} \alpha$ was correlated with the HOMA-IR index, confirming the role of this cytokine in the development of hepatic insulin resistance [62].

In conclusion, the present study showed that a soybean diet prevented steatosis at least in part through reduced lipogenesis but resulted in TNF $\alpha$-mediated inflammation.

\section{Conflict of Interests}

The authors declare that there is no conflict of interests regarding the publication of this paper. 


\section{Authors' Contributions}

Márcia Queiroz Latorraca and Marise Auxiliadora de Barros Reis designed research; Sílvia Regina de Lima Reis, Naoel Hassan Feres, Leticia Martins Ignacio-Souza, and Bárbara Laet Botosso conducted research; Edson Moleta Colodel carried out the liver histology; Vanessa Cristina Arantes and Roberto Vilela Veloso carried out the RIA and interpretation of data; Nair Honda Kawashita carried out the enzymatic assays. Márcia Queiroz Latorraca and Sílvia Regina de Lima Reis performed statistical analysis and wrote the paper. Sílvia Regina de Lima Reis had primary responsibility for final content. All authors read and approved the paper.

\section{Acknowledgments}

The authors thank Celso Roberto Afonso for the technical assistance. This work is part of a dissertation presented by Sílvia Regina de Lima Reis as partial fulfillment of the requirements for a Master's Degree in Health Sciences at the Faculty of Medical Sciences, Universidade Federal de Mato Grosso. This work was partly supported by the Brazilian foundations FAPEMAT (Grant 175/04), CNPq (Grant 479138/2003-6), and FINEP/PRONEX (Grant 134/97).

\section{References}

[1] L. A. Adams, P. Angulo, and K. D. Lindor, "Nonalcoholic fatty liver disease," CMAJ, vol. 172, no. 7, pp. 899-905, 2005.

[2] J. D. Browning and J. D. Horton, "Molecular mediators of hepatic steatosis and liver injury," Journal of Clinical Investigation, vol. 114, no. 2, pp. 147-152, 2004.

[3] B. A. Neuschwander-Tetri and S. H. Caldwell, "Nonalcoholic steatohepatitis: summary of an AASLD Single Topic Conference," Hepatology, vol. 37, no. 5, pp. 1202-1219, 2003.

[4] P. Angulo, "Nonalcoholic fatty liver disease," The New England Journal of Medicine, vol. 346, no. 16, pp. 1221-1231, 2002.

[5] K. Qureshi and G. A. Abrams, "Metabolic liver disease of obesity and role of adipose tissue in the pathogenesis of nonalcoholic fatty liver disease," World Journal of Gastroenterology, vol. 13, no. 26, pp. 3540-3553, 2007.

[6] G. Marchesini, M. Brizi, A. M. Morselli-Labate et al., "Association of nonalcoholic fatty liver disease with insulin resistance," The American Journal of Medicine, vol. 107, no. 5, pp. 450-455, 1999.

[7] K. L. Donnelly, C. I. Smith, S. J. Schwarzenberg, J. Jessurun, M. D. Boldt, and E. J. Parks, "Sources of fatty acids stored in liver and secreted via lipoproteins in patients with nonalcoholic fatty liver disease," The Journal of Clinical Investigation, vol. 115, no. 5, pp. 1343-1351, 2005.

[8] G. F. Lewis, A. Carpentier, K. Adeli, and A. Giacca, "Disordered fat storage and mobilization in the pathogenesis of insulin resistance and type 2 diabetes," Endocrine Reviews, vol. 23, no. 2, pp. 201-229, 2002.

[9] I. Shimomura, Y. Bashmakov, and J. D. Horton, "Increased levels of nuclear SREBP-1c associated with fatty livers in two mouse models of diabetes mellitus," The Journal of Biological Chemistry, vol. 274, no. 42, pp. 30028-30032, 1999.

[10] M. Foretz, C. Pacot, I. Dugail et al., "ADD1/SREBP-1c is required in the activation of hepatic lipogenic gene expression by glucose," Molecular and Cellular Biology, vol. 19, no. 5, pp. 3760-3768, 1999.

[11] U. Edvardsson, M. Bergström, M. Alexandersson, K. Bamberg, B. Ljung, and B. Dahllöf, "Rosiglitazone (BRL49653), a PPAR $\gamma$-selective agonist, causes peroxisome proliferator-like liver effects in obese mice," Journal of Lipid Research, vol. 40, no. 7, pp. 1177-1184, 1999.

[12] Q.-G. Deng, H. She, J. H. Cheng et al., "Steatohepatitis induced by intragastric overfeeding in mice," Hepatology, vol. 42 , no. 4 , pp. 905-914, 2005.

[13] E. Mas, M. Danjoux, V. Garcia, S. Carpentier, B. Ségul, and T. Levade, "IL-6 deficiency attenuates murine diet-induced nonalcoholic steatohepatitis," PLoS ONE, vol. 4, no. 11, Article ID e7929, 2009.

[14] J. Crespo, A. Cayoen, P. Fernendez-Gil et al., "Gene expression of tumor necrosis factor $\alpha$ and TNF-receptors, p55 and p75, in nonalcoholic steatohepatitis patients," Hepatology, vol. 34, no. 6, pp. 1158-1163, 2001.

[15] R. G. Baker, M. S. Hayden, and S. Ghosh, "NF- $\kappa$ B, inflammation, and metabolic disease," Cell Metabolism, vol. 13, no. 1, pp. 11-22, 2011.

[16] M. Asrih and F. R. Jornayvaz, "Inflammation as a potential link between nonalcoholic fatty liver disease and insulin resistance," Journal of Endocrinology, vol. 218, no. 3, pp. R25-R36, 2013.

[17] A. L. Menezes, M. P. Pereira, S. L. Buzelle et al., "A low-protein, high-carbohydrate diet increases de novo fatty acid synthesis from glycerol and glycerokinase content in the liver of growing rats," Nutrition Research, vol. 33, no. 6, pp. 494-502, 2013.

[18] M. Q. Latorraca, M. A. B. Reis, E. M. Carneiro et al., "Protein deficiency and nutritional recovery modulate insulin secretion and the early steps of insulin action in rats," Journal of Nutrition, vol. 128, no. 10, pp. 1643-1649, 1998.

[19] S. E. Ozanne, G. D. Smith, J. Tikerpae, and C. N. Hales, "Altered regulation of hepatic glucose output in the male offspring of protein-malnourished rat dams," American Journal of Physiology: Endocrinology and Metabolism, vol. 270, no. 4, pp. E559-E564, 1996.

[20] M. Q. Latorraca, L. F. Stoppiglia, M. H. G. Gomes-da-Silva et al., "Effect of the soybean flour diet on insulin secretion and action," in Flour and Breads and Their Fortification in Health and Disease Prevention, V. Preedy, R. Watson, and V. Patel, Eds., pp. 495-506, Elsevier, London, UK, 1st edition, 2011.

[21] N. Torres, I. Torre-Villalvazo, and A. R. Tovar, "Regulation of lipid metabolism by soy protein and its implication in diseases mediated by lipid disorders," The Journal of Nutritional Biochemistry, vol. 17, no. 6, pp. 365-373, 2006.

[22] O. Mezei, W. J. Banz, R. W. Steger, M. R. Peluso, T. A. Winters, and N. Shay, "Soy isoflavones exert antidiabetic and hypolipidemic effects through the PPAR pathways in obese Zucker rats and murine RAW 264.7 cells," Journal of Nutrition, vol. 133, no. 5, pp. 1238-1243, 2003.

[23] E. D. A. Oliveira, L. M. G. Cheim, R. V. Veloso et al., "Nutritional recovery with a soybean flour diet improves the insulin response to a glucose load without modifying glucose homeostasis," Nutrition, vol. 24, no. 1, pp. 76-83, 2008.

[24] N. H. Feres, S. R. de Lima Reis, R. V. Veloso et al., "Soybean diet alters the insulin-signaling pathway in the liver of rats recovering from early-life malnutrition," Nutrition, vol. 26, no. 4, pp. 441-448, 2010.

[25] A. A. Paiva, J. Z. Faiad, M. S. Taki et al., "A soyabean diet does not modify the activity of brown adipose tissue but alters the rate 
of lipolysis in the retroperitoneal white adipose tissue of male rats recovering from early-life malnutrition," British Journal of Nutrition, vol. 108, no. 6, pp. 1042-1051, 2012.

[26] R. V. Veloso, M. Q. Latorraca, V. C. Arantes et al., "Soybean diet improves insulin secretion through activation of CAMP/PKA pathway in rats," The Journal of Nutritional Biochemistry, vol. 19, no. 11, pp. 778-784, 2008.

[27] W. Q. Wolfson, C. Chon et al., "A rapid procedure for the estimation of total protein, true albumin, total globulin, alpha globulin, beta globulin and gamma globulin in $1.0 \mathrm{ml}$ of serum," The American Journal of Clinical Pathology, vol. 18, no. 9, pp. 723-730, 1948.

[28] A. M. Scott, I. Atwater, and E. Rojas, "A method for the simultaneous measurement of insulin release and B cell membrane potential in single mouse islets of Langerhans," Diabetologia, vol. 21, no. 5, pp. 470-475, 1981.

[29] S. Ochoa, "Malic enzyme," Methods Enzymology, vol. 1, pp. 739753, 1951.

[30] R. Y. Hsu and H. Lardy, "Malic enzyme," Methods Enzymology, vol. 1, pp. 230-235, 1969.

[31] P. A. Srere, "The citrate cleavage enzyme. I. Distribution and purification," The Journal of Biological Chemistry, vol. 234, pp. 2544-2547, 1959.

[32] J. Folch, M. Lees, and G. H. S. Stanley, "A simple method for the isolation and purification of total lipides from animal tissues," The Journal of Biological Chemistry, vol. 226, no. 1, pp. 497-509, 1957.

[33] R. H. Migliorini and C. Linder, "Oxytocin and lipogenesis by adipose tissue in vitro," Biochimica et Biophysica Acta: Lipids and Lipid Metabolism, vol. 125, no. 2, pp. 392-394, 1966.

[34] M. M. Bradford, "A rapid and sensitive method for the quantitation of microgram quantities of protein utilizing the principle of protein dye binding," Analytical Biochemistry, vol. 72, no. 1-2, pp. 248-254, 1976.

[35] U. K. Laemmli, "Cleavage of structural proteins during the assembly of the head of bacteriophage T4," Nature, vol. 227, no. 5259, pp. 680-685, 1970.

[36] C. A. Siegrist-Kaiser, V. Pauli, C. E. Juge-Aubry et al., "Direct effects of leptin on brown and white adipose tissue," Journal of Clinical Investigation, vol. 100, no. 11, pp. 2858-2864, 1997.

[37] M. Milanski, K. L. A. Souza, S. R. L. Reis et al., "Soybean diet modulates acetyl-coenzyme A carboxylase expression in livers of rats recovering from early-life malnutrition," Nutrition, vol. 25, no. 7-8, pp. 774-781, 2009.

[38] R. R. Sokal and F. J. Rohlf, "Assumptions of analysis of variance," in The Principles and Practice of Statistics in Biological Research, R. R. Sokal and F. J. Rohlf, Eds., pp. 392-450, W. H. Freeman, New York, NY, USA, 1995.

[39] N. Baba, H. Radwan, and T. V. Itallie, "Effects of casein versus soyprotein diets on body composition and serum lipid levels in adult rats," Nutrition Research, vol. 12, no. 2, pp. 279-288, 1992.

[40] L. Bu, K. D. R. Setchell, and E. D. Lephart, "Influences of dietary soy isoflavones on metabolism but not nociception and stress hormone responses in ovariectomized female rats," Reproductive Biology and Endocrinology, vol. 3, article 58, 2005.

[41] S. Zhan and S. C. Ho, "Meta-analysis of the effects of soy protein containing isoflavones on the lipid profile," The American Journal of Clinical Nutrition, vol. 81, no. 2, pp. 397-408, 2005.

[42] C. Ascencio, N. Torres, F. Isoard-Acosta, F. J. Gómez-Pérez, R. Hernández-Pando, and A. R. Tovar, "Soy protein affects serum insulin and hepatic SREBP-1 mRNA and reduces fatty liver in rats," Journal of Nutrition, vol. 134, no. 3, pp. 522-529, 2004.
[43] A. R. Tovar, C. Ascencio, and N. Torres, "Soy protein, casein, and zein regulate histidase gene expression by modulating serum glucagon," American Journal of Physiology-Endocrinology and Metabolism, vol. 283, no. 5, pp. E1016-E1022, 2002.

[44] B. Vozarova, N. Stefan, R. S. Lindsay et al., "High alanine aminotransferase is associated with decreased hepatic insulin sensitivity and predicts the development of type 2 diabetes," Diabetes, vol. 51, no. 6, pp. 1889-1895, 2002.

[45] L. P. Moura, G. A. Figueredo, N. O. Bertolini et al., "Dietary restriction, caloric value and the accumulation of hepatic fat," Lipids in Health and Disease, vol. 11, article 2, 2012.

[46] K. Tobe, R. Suzuki, M. Aoyama et al., "Increased expression of the sterol regulatory element-binding protein-1 gene in insulin receptor substrate- $2^{-/-}$mouse liver," The Journal of Biological Chemistry, vol. 276, no. 42, pp. 38337-38340, 2001.

[47] E. S. Shin, H. H. Lee, S. Y. Cho, H. W. Park, S. J. Lee, and T. R. Lee, "Genistein downregulates SREBP-1 regulated gene expression by inhibiting site-1 protease expression in HepG2 cells," Journal of Nutrition, vol. 137, no. 5, pp. 1127-1131, 2007.

[48] A. H. Hasty, H. Shimano, J.-I. Osuga et al., "Severe hypercholesterolemia, hypertriglyceridemia, and atherosclerosis in mice lacking both leptin and the low density lipoprotein receptor," The Journal of Biological Chemistry, vol. 276, no. 40, pp. 3740237408, 2001.

[49] A. IJpenberg, E. Jeannin, W. Wahli, and B. Desvergne, "Polarity and specific sequence requirements of peroxisome proliferatoractivated receptor (PPAR)/retinoid X receptor heterodimer binding to DNA. A functional analysis of the malic enzyme gene PPAR response element," The Journal of Biological Chemistry, vol. 272, no. 32, pp. 20108-20117, 1997.

[50] K. Matsusue, M. Haluzik, G. Lambert et al., "Liver-specific disruption of PPAR $\gamma$ in leptin-deficient mice improves fatty liver but aggravates diabetic phenotypes," The Journal of Clinical Investigation, vol. 111, no. 5, pp. 737-747, 2003.

[51] O. Gavrilova, M. Haluzik, K. Matsusue et al., "Liver peroxisome proliferator-activated receptor $\gamma$ contributes to hepatic steatosis, triglyceride clearance, and regulation of body fat mass," The Journal of Biological Chemistry, vol. 278, no. 36, pp. 3426834276, 2003.

[52] R. L. Drake, "Effects of various insulin dosages on hepatic lipogenesis," Anatomical Record, vol. 220, no. 3, pp. 300-304, 1988.

[53] M. Boll, L. W. D. Weber, and A. Stampfl, "Nutritional regulation of the activities of lipogenic enzymes of rat liver and brown adipose tissue," Zeitschrift für Naturforschung C, vol. 51, no. 1112, pp. 859-869, 1996.

[54] L. A. Adams and P. Angulo, "Role of liver biopsy and serum markers of liver fibrosis in non-alcoholic fatty liver disease," Clinics in Liver Disease, vol. 11, no. 1, pp. 25-35, 2007.

[55] R. M. McClain, E. Wolz, A. Davidovich, F. Pfannkuch, J. A. Edwards, and J. Bausch, "Acute, subchronic and chronic safety studies with genistein in rats," Food and Chemical Toxicology, vol. 44, no. 1, pp. 56-80, 2006.

[56] S. Kim, H.-J. Shin, S. Y. Kim et al., "Genistein enhances expression of genes involved in fatty acid catabolism through activation of PPAR $\alpha$, Molecular and Cellular Endocrinology, vol. 220, no. 1-2, pp. 51-58, 2004.

[57] S. Mandard, M. Müller, and S. Kersten, "Peroxisome proliferator-activated receptor $\alpha$ target genes," Cellular and Molecular Life Sciences, vol. 61, no. 4, pp. 393-416, 2004.

[58] E. Ip, G. C. Farrell, G. Robertson, P. Hall, R. Kirsch, and I. Leclercq, "Central role of PPAR $\alpha$-dependent hepatic lipid 
turnover in dietary steatohepatitis in mice," Hepatology, vol. 38, no. 1, pp. 123-132, 2003.

[59] K. Yamaguchi, L. Yang, S. McCall et al., "Inhibiting triglyceride synthesis improves hepatic steatosis but exacerbates liver damage and fibrosis in obese mice with nonalcoholic steatohepatitis," Hepatology, vol. 45, no. 6, pp. 1366-1374, 2007.

[60] L. Abu-Elheiga, M. M. Matzuk, K. A. H. Abo-Hashema, and S. J. Wakil, "Continuous fatty acid oxidation and reduced fat storage in mice lacking acetyl-coa carboxylase 2," Science, vol. 291, no. 5513, pp. 2613-2616, 2001.

[61] T. Luedde and R. F. Schwabe, "NF- $\kappa$ B in the liver-linking injury, fibrosis and hepatocellular carcinoma," Nature Reviews Gastroenterology \& Hepatology, vol. 8, no. 2, pp. 108-118, 2011.

[62] L. Li, Q. He, X. Huang et al., "NOX3-derived reactive oxygen species promote TNF- $\alpha$-induced reductions in hepatocyte glycogen levels via a JNK pathway," FEBS Letters, vol. 584, no. 5, pp. 995-1000, 2010. 


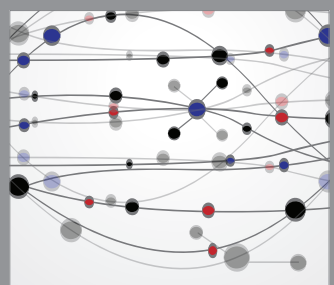

The Scientific World Journal
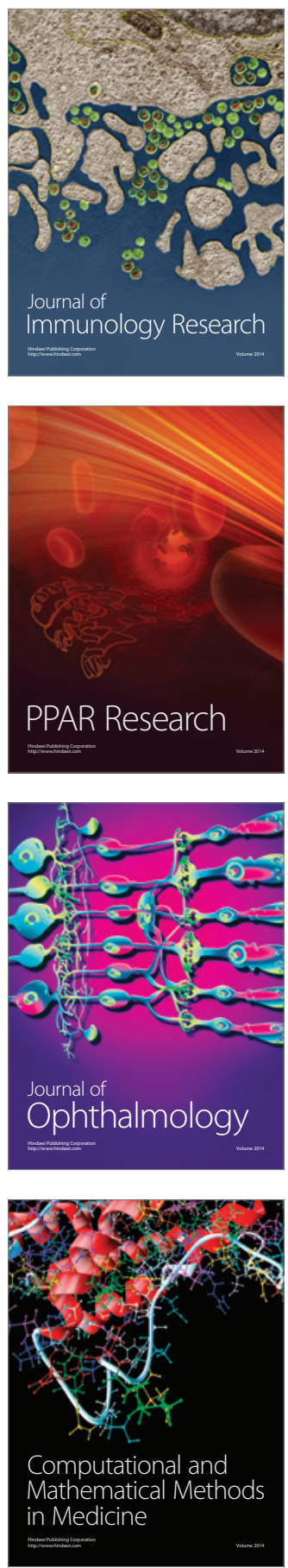

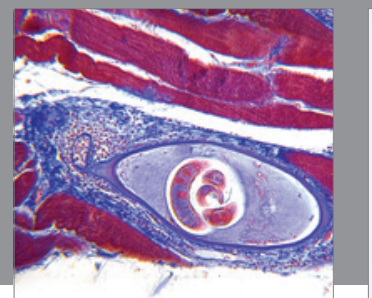

Gastroenterology

Research and Practice
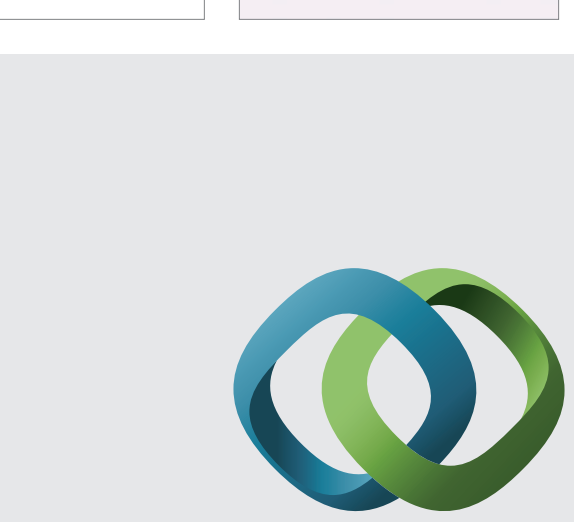

\section{Hindawi}

Submit your manuscripts at

http://www.hindawi.com
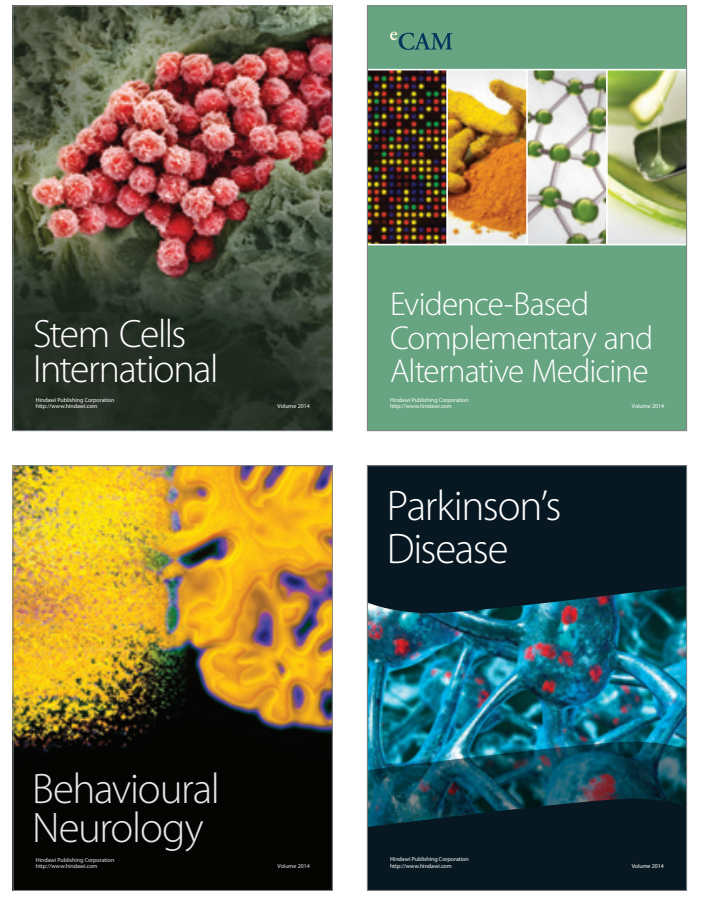
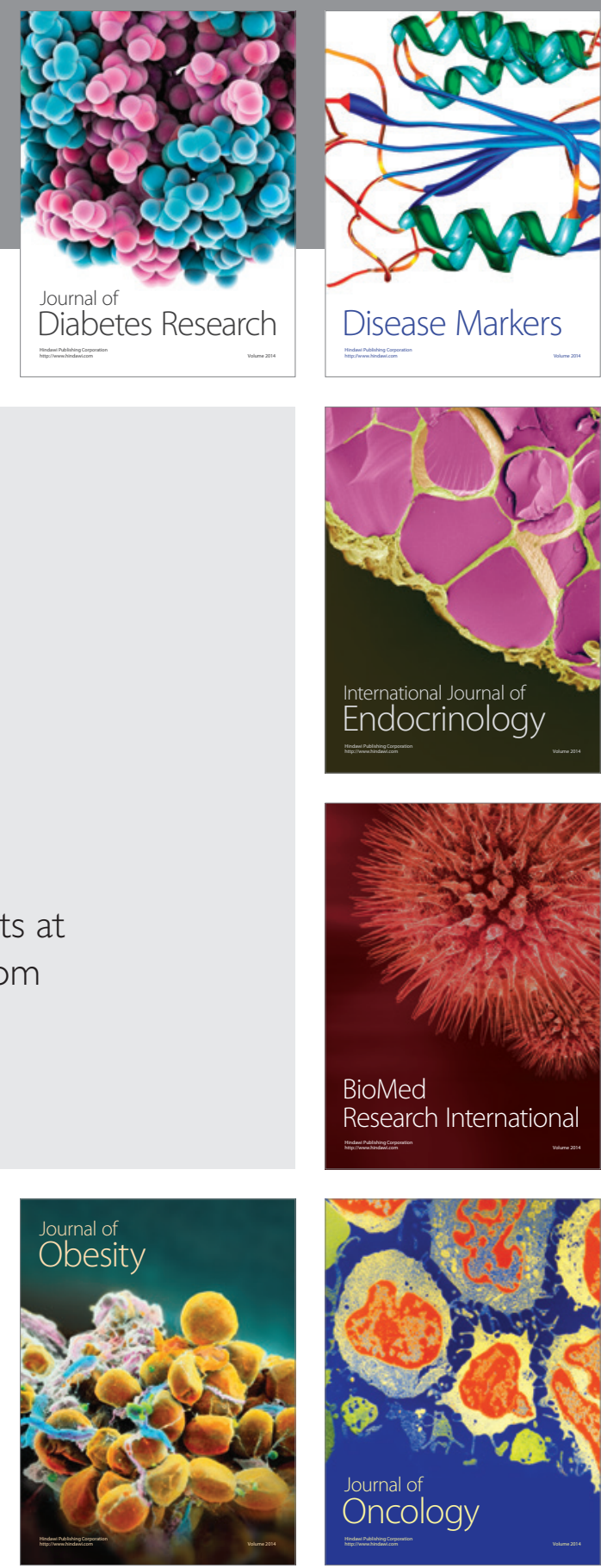

Disease Markers
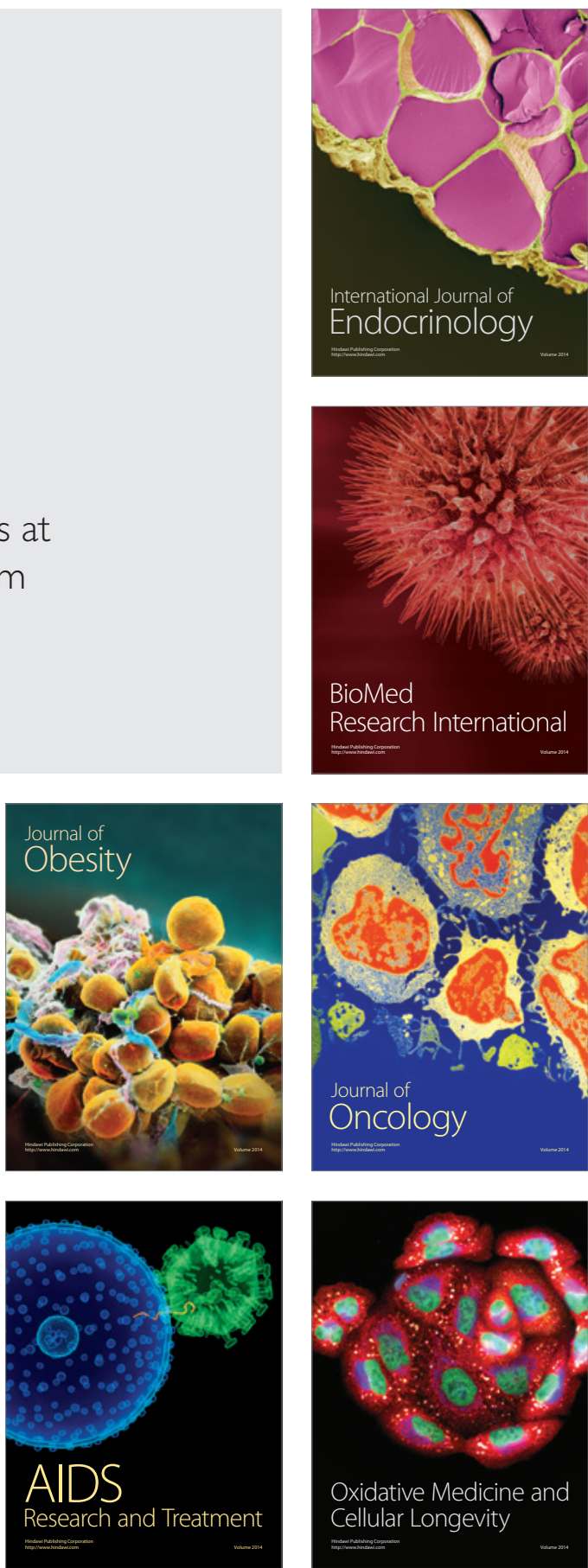